\title{
DESKRIPSI IDENTITAS MASYARAKAT CIOMAS DALAM SASTRA LISAN GOLOK CIOMAS DI KABUPATEN SERANG BANTEN
}

\author{
Nurholis \\ Pascasarjana Universitas Padjadjaran \\ nurholis79@gmail.com
}

\begin{abstract}
Tujuan dari penelitian ini adalah untuk menggali identitas masyarakat Ciomas berdasarkan cerita rakyat kemudian bagaimana identitas tersebut dikonstruksi. Data berupa cerita rakyat golok Ciomas, hasil wawancara, hasil observasi, dan hasil angket. Teknik analisis yang digunakan adalah teknik analisis isi. Adapun hasilnya adalah; identitas masyarakat Ciomas berdasarkan cerita mencakup tentang menjunjung tinggi dilaksanakannya adat-istiadat, dan percaya pada hal-hal yang bersifat gaib/mistis. Dari segi kepribadian, masyarakat Ciomas adalah masyarakat yang pemberani, bersemangat, dan mudah iba kepada orang lain. Dari segi kemasyarakatan, masyarakat Ciomas suka bekerjasama, bergotong royong dan suka menolong. Dari segi kealaman (kaitannya dengan alam) masyarakat Ciomas adalah masyarakat yang sangat dekat dengan alam, merawat dan menghargai alam semesta. Dalam bidang ekonomi masyarakat Ciomas mengenal sistem kerja sama, dan dalam bidang agama serta budaya memberi warna bagi identitas masyarakat Ciomas.
\end{abstract}

Kata Kunci: Golok Ciomas, Identitas, Konstruksi, Representasi

\section{PENDAHULUAN}

Kecamatan Ciomas merupakan salah satu dari 29 (dua puluh sembilan) Kecamatan di Kabupaten Serang Provinsi Banten. Secara geografis Kec. Ciomas terletak di Kab. Serang bagian selatan. Sebelah Barat Kec. Ciomas berbatasan dengan Kec. Padarincang dan Kab. Pandenglang, sebelah Utara berbatasan dengan Kec. Padarincang dan Pabuaran, sebelah Timur perbatasan dengan Kec. Baros dan Pandeglang sedangkan sebelah Selatan perbatasan dengan Kab. Pandeglang. (BPSKS, 2015:1). Ciomas sangat terkenal dengan Cerita Golok-nya yaitu "Cerita Golok Ciomas" kemudian disingkat menjadi (CGC) yang merepresentasikan sebuah identitas masyarakat tersebut.
Cerita rakyat sendiri merupakan salah satu bagian dari karya sastra/tradisi lisan, yang berbentuk prosa, dilisankan dan dipercayai oleh masyarakat tertentu yang sarat akan makna dan dibangun berdasarkan ide, gagasan, pikiran, perasaan, dan pendapat pencerita untuk disampaikan kepada orang lain. Sebagai bagian dari karya sastra, cerita rakyat tentu saja di dalamnya terdapat gambaran budaya, karena cerita rakyat dibuat oleh makhluk berbudaya (manusia). Nilainilai kebudayaan tersebut sebagai pembangun tema, karakter tokoh, latar, alur, dan amanat. Oleh karena itu, cerita rakyat sangat dipercayai oleh masyarakat setempat sebagai satu pedoman sehingga masyarakat dulu tidak kehabisan cara dalam menyampaikan cerita rakyat kepada 
generasi berikutnya. Seperti menceritakannya menjelang tidur, atau dalam satu perkumpulan di desa.

Karya sastra/tradisi lisan mempunyai ciri-ciri khusus, menurut penjelasan Jan Harold Brunvand, (1996:4), bahwa cerita rakyat mempunyai ciri-ciri pengenal; ... it is oral; It is traditional; It exists in different versions; It is usually anonymous; It tends to become formularized. Sejalan dengan hal ini, Danandjaja, (1994: 1-4) menjelaskan bahwa, sastra lisan merupakan bagian dari kebudayaan kolektif (milik bersama) yang tersebar dan diwariskan secara turun-temurun secara tradisional dalam versi-versi bahkan varian yang berbeda, baik dalam bentuk lisan maupun disertai contoh dengan gerak isyarat atau alat bantu pengingat. Juga penyebaran dan perwarisan sastra lisan bersifat lisan; bersifat tradisional; ada (exist); bersifat anonim; mempunyai kegunaan (fungsi) dalam kehidupan bersama dan pralogis; pada umumnya bersifat polos dan lugu. pendapat Harvey (1955:294) yang menyatakan bahwa; ...that is the traditional beliefs, legends, and customs, current among the common people and the study of them. Sehingga sastra lisan disebarkan secara lisan dari mulut ke mulut dari generasi ke generasi.

Menurut pendapat Ruth Finnegan dalam penjelasan Okke K.S. Zaimar (2015:378) bahwa sastra/tradisi lisan, penyebaran, komposisi, maupun pertunjukkannya dilakukan melalui kata-kata dari mulut ke mulut dan bukan melalui kata-kata yang tertulis atau tercetak. Kemudian Finnegan menekankan bahwa karya dapat pula disebut sastra/tradisi lisan dengan melihat ketiga aspeknya, yaitu komposisi, cara penyampaiannya dan pertunjukannya. Sastra/tradisi lisan ini tidak selalu bersifat naratif. Berbagai teks lisan (di sini istilah teks digunakan bukan hanya untuk yang tertulis, yang dimaksud dengan teks di sini adalah wacana) yang tidak naratif pun dapat dianggap sebagai sastra lisan, misalnya cerita rakyat yang lahir dari suatu kelompok masyarakat, tumbuh dan berkembang secara lisan dan hidup turun temurun.

Sebagai bagian dari 'warisan budaya', cerita rakyat sebagai karya/sastra lisan bukan hanya untuk dituliskan semata, tetapi perlu dilakukan suatu penelitian agar bisa diambil fungsi dan manfaatnya. Penelitian tentang cerita rakyat di suatu daerah pun sangat perlu dilakukan guna menemukan eksistensi dan untuk menentukan identitas masyarakat daerah itu sendiri. Di daerah Ciomas Kab. Serang mempunyai cerita rakyat, yaitu CGC yang sarat akan nilai seni dan budayanya.

Sastra lisan CGC dipilih karena mempunyai perbedaan dan keistimewaan dengan cerita rakyat lainnya yang ada di daerah Kab. Serang Banten. Keistimewaan dari CGC ini wujud benda visualnya ada di lingkungan masyarakat Ciomas yaitu berupa Golok dan Palu Nyi Denok. Juga adanya pemahaman tentang CGC yang menjadi sakral hingga menarik pemahaman pada 'menyucikan' atau 'mengkuduskan' kebenaran CGC tersebut pada wilayah simbolik juga sistem kepercayaan yang diungkapkan dalam bentuk cerita dan mitos. Dalam hal ini, cerita dan mitos CGC merujuk kepada sistem-sistem kepercayaan dengan makna kultural dan menjustifikasi, melandasi, 
mengontrol, melegitimasi, dan mengatur tindakan-tindakan setiap anggota masyarakat Ciomas sehingga pikiran setiap anggota masyarakat terkonstruksi oleh substansi CGC yang dimilikinya hingga mengatur kehidupan sosial masyarakatnya.

CGC sendiri dituturkan oleh seseorang yang secara otoritas adat dapat menceritakan cerita tersebut kepada masyarakat setempat. Cerita ini juga mengukuhkan jati diri masyarakat Ciomas Kab. Serang dengan citra-citra yang selama ini melekat dan dianggap sebagai orang yang keras, berani, sangar. Juga mengukuhkan image Jawara (pemimpin masyarakat yang dianggap mempunyai keberanian dan ilmu magis) yang selama ini seringkali dikonotasikan sebagai sosok yang keras, berani, bertutur kata sompral, dan selalu memakai pakaian hitam dan membawa golok.

Selain bentuk penyembaran sastra lisan golok Ciomas ini melalui tuturan, lembaga pendidikan dan pengembangan potensi sumber daya masyarakat daerah Banten (LP3SDMDB) yang bekerjasama dengan Persatuan Guru Republik Indonesia (PGRI) Provinsi Banten juga berupaya memperkenalkan identitas masyarakat Ciomas melalui CGC dengan cara dicetak dan dipublikasikan serta diserbarkan. Upaya ini memunculkan sebuah "wacana tandingan" yang merepresentasikan wacana mengenai identitas masyarakat Ciomas secara khusus, dan umumnya masyarakat di luar Provinsi Banten. Penentuan identitas masyarakat Ciomas ini akan mudah diakui dan dianggap benar oleh masyarakatnya jika dilegalkan oleh suatu institusi pemerintah.
Penyebaran wacana yang dilakukan oleh lembaga pemerintah ini dianggap benar oleh masyarakat karena memiliki legalitas yang terakui. Berbeda halnya dengan wacana yang dikeluarkan oleh kelompok masyarakat tertentu belum tentu dianggap benar oleh masyarakat luas. Oleh karena itu, penyebaran wacana yang di dalamnya terdapat 'pesan' atau 'gagasan' tertentu akan mudah diakui oleh masyarakat jika penyebaran wacana tersebut dilakukan oleh pihak pemerintah. Sehingga dapat mengarahkan pada sudut pandang dan pemikiran mengenai bentuk konstruksi identitas masyarakat Ciomas di Kab. Serang antara cerita, dengan identitas dalam struktur sosial masyarakat, serta identitas masyarakat Ciomas sebagai penentu (pihak) yang dilestarikan oleh keadaan. Hal ini tampak bukan saja ceritanya sebagai sumber dan pemberi legitimasi kuasa tersebut, melainkan adanya unsur timbal balik antar keduanya yang memperoleh keberuntungan, yaitu mencapai kelestariannya.

Oleh karena itu, penyebaran wacana yang di dalamnya terdapat 'pesan' atau 'gagasan' tertentu akan mudah diakui oleh masyarakat luas jika penyebaran wacana tersebut dilakukan oleh pihak pemerintah Kabupaten Serang. Hal yang perlu disikapi dalam memandang sastra lisan golok Ciomas ini adalah sebuah identitas yang mewakili semua wilayah sehingga menjadi bagian wilayahnya. Selain permasalahan di atas, sastra lisan golok Ciomas ini sebagai bagian dari kajian antropologi sastra karena masalah identitas masyarakat Ciomas Kab. Serang Banten hingga kini belum terselesaikan dengan baik. Mengutip 
pernyataam Fadillah (2005) yang mengemukakan bahwa, penentuan identitas masyarakat Ciomas Kab. Serang, baik kesenian, maupun pakaian, hingga kini belum dapat ditentukan. Permasalahan itu timbul karena Banten merupakan sphere of interaction berbagai model budaya, tempat bertemunya kelompokkelompok pembawa identitas, baik berbasiskan agama, etnik atau ras, maupun status sosial. Penentuan identitas masyarakat Ciomas ini sulit ditentukan karena keragaman etnik dan keragaman budayanya yang ada di Kab. Serang Banten secara umum. Oleh karena itu, permasalahan pengungkapan identitas dengan melalui sastra lisan golok Ciomas ini menjadi penting untuk dilakukan.

\section{Landasan Teori}

Sastra dapat dipandang sebagai cermin kehidupan, tanggapan terhadap kehidupan, sekaligus sebagai evaluasi terhadap kehidupan. Melalui karya sastra dapat dibayangkan tingkat kemajuan kebudayaan, gambaran tradisi yang sedang berlaku, tingkat kehidupan yang sudah dicapai oleh masyarakat pada suatu masa serta usaha pemecahannya sesuai dengan citacita mereka.

Perjalanan tradisi lisan telah hampir sama tuanya dengan kehidupan manusia. Sejak manusia ada, mereka sudah memiliki tradisi lisan yang dimiliki oleh sekelompok masyarakat tertentu. Keberadaannya diakui, bahkan sangat dekat dengan kelompok masyarakat yang memilikinya. Sebagai bagian dari "warisan budaya", cerita rakyat sebagai sastra lisan yang merepresentasikan berbagai bentuk kebudayaan dari masyarakat penuturnya bukan hanya untuk dituliskan semata, tetapi perlu dilakukan suatu penelitian agar bisa diambil pesan-pesan berupa nilai dan manfaatnya bagi kehidupan. Oleh karena itu, tradisi lisan merupakan ingatan kolektif masyarakat pemiliknya, tentang kebudayaannya, latar sosial, sistem kepercayaan masyarakat, sistem religinya, dan lain sebagainya. Selain itu, cerita rakyat tersebut mengungkapkan secara sadar atau tidak sadar, bagaimana kelompok masyarakat pemilik atau pendukung cerita rakyat itu berfikir. Cerita rakyat juga mengabadikan dan melestarikan apa yang dirasakan penting.

\section{Teori Identitas}

Penampilan wacana identitas dalam sastra lisan golok Ciomas ini menampilkan beragam maksud di dalam wacana lisan/teks dan efeknya yang bermacam-macam hadir di tengah masyarakat Ciomas Kab. Serang. Selain penyebarannya melalui bentuk tuturan dari sang guru kunci sebagai pemegang otoritas adat yang ada di masyarakat Ciomas, juga dihadirkannya sastra lisan Golok Ciomas ke dalam bentuk cetak yang disebarkan oleh aparat Pemerintah Kabupaten Serang. Hal ini merupakan bentuk dan efek-efek yang timbul dari penampilan wacana tersebut, dapat diungkap dengan menghubungkan bahasa-bahasa yang ada di dalam wacana lisan/teks dengan konteks-konteks yang melingkupi teks tersebut.

Johnstone (2002:

mengemukakan bahwa penampilan identitas dapat dianalisis dengan menyoroti aspek identitas sebagai praktik wacana. Praktik wacana menimbang bagaimana penampilan suatu teks hadir di tengah masyarakat dengan berbagai maksud dan 
konteks. Penampilan wacana identitas melibatkan banyak konteks, di antaranya situasi di mana teks diproduksi dan partisipan di dalam teks. Selain itu, konteks yang dimaksud dapat berupa aspek-aspek sosial, budaya, dan politik yang berpengaruh pada proses produksi teks tersebut. Dengan demikian, pendekatan ini melihat identitas sebagai persoalan penyajian itu sendiri dengan melibatkan teks dan konteksnya.

Menurut Stuart Hall (1994), identitas diartikan sebagai sesuatu yang bersifat imajiner atau diimajinasikan tentang keutuhan. Identitas sendiri muncul akibat dari perasaan bimbang, yang kemudian diisi oleh kekuatan dari luar dari setiap individu. Dengan begitu identitas selalu berproses, selalu akan terbentuk di dalam, bukan di luarrepresentasi. Identitas sendiri adalah sebuah perwujudan dari imajinasi yang dipandang oleh pihak-pihak tertentu yang saling terhubung di dalamnya. Sehingga dapat diartikan bahwa identitas adalah representasi diri melalui seseorang atau masyarakat melihat dirinya sendiri, dan bagaimana orang lain melihat mereka sebagai sebuah entitas sosialbudaya. Dengan kata lain bahwa, identitas adalah sebuah ciri, tanda, sifat, atau jati diri yang khas yang melekat pada seseorang atau kelompok yang berfungsi untuk membedakan satu orang atau satu kelompok dengan yang lain.

Lebih lanjut Stuart Hall (1990: 393) dalam Cultural Identity and Diaspora menjelaskan bahwa, identitas setidaknya bisa dilihat dari dua cara pandang, yaitu identitas sebagai wujud (identity as being) dan identitas sebagai proses menjadi (identity as becaming). Dalam cara pandang pertama, identitas dilihat sebagai suatu kesatuan yang dimiliki bersama atau merupakan bentuk dasar seseorang serta berada dalam diri banyak orang yang memiliki kesamaan sejarah dan leluhur. Sehingga pandangan ini lebih melihat bahwasanya ciri fisik atau lahiriyah lebih mengidentifikasi mereka sebagai suatu kelompok. Artinya bahwa, identitas merupakan sebuah bagian dari konsep diri seseorang yang berasal dari pengetahuan dan perasaan seseorang yang menjadi bagian dari sebuah kelompok budaya tertentu. identitas lebih menekankan kepada seberapa besar seseorang merasa sebagai bagian dari sebuah kelompok budaya tertentu dan bagaimana hal tersebut mempengaruhi perasaan, persepsi dan perilakunya.

Identitas adalah sesuatu yang dibentuk dari sebuah konstruksi sosial dan bukan merupakan pembawaan maupun suatu produk, namun lebih cenderung dikatakan sebagai suatu proses yang berlangsung dalam momen-momen yang spesifik dan interaksional De Fina et all, 2006: 2). Suatu identitas tidak lahir karena suatu pembawaan atau sesuatu yang dihasilkan. Identitas hadir di tengah masyarakat sebagai sesuatu yang dibentuk dari hasil interaksi sosial yang dibangun oleh masyarakat itu sendiri. Dengan kata lain bahwa identitas berkaitan dengan belonging tentang persamaan dengan sejumlah orang dan apa yang membedakan seseorang dengan yang lain.

Mengutip penjelasan dari Thornborrow dalam Abdul Syukur Ibrahim (ed.) Bahasa, Masyarakat, dan Kekuasaan (2007: 238) yang menyatakan bahwa seseorang akan 
dianggap sebagai anggota dari kelompok itu, baik dalam pandangan orang-orang dalam kelompok itu sendiri maupun dalam pandangan orang-orang di luar kelompok itu, jika dia dapat menunjukkan bahwa ia mampu menggunakan istilah-istilah bahasa yang tepat sesuai dengan norma-norma dari sebuah kelompok tertentu. Suatu identitas diakui dan dapat diterima oleh suatu kelompok jika identitas itu dikenal dan diakui oleh kelompok tersebut sebagai bagian dari kelompoknya. Pengakuan identitas sebagai representasi suatu kelompok dapat pula dilihat dari sudut pandang orang yang berada di luar kelompok. Salah satu hal yang dapat dijadikan patokan dalam memandang suatu identitas sebagai bagian dari kelompok adalah penggunaan istilah-istilah bahasa.

Menurut Stuart Hall, identitas tidak dapat dilepaskan dari 'sense (rasa/kesadaran) terhadap ikatan kolektivitas'. Dari pernyataan tersebut, maka ketika identitas diformulasikan sebagai sesuatu yang membuat seseorang memiliki berbagai persamaan dengan orang lain, maka pada saat yang bersamaan juga identitas memformulasikan otherness (keberbedaan) atau sesuatu yang di luar persamaan-persamaan tersebut. Sehingga karakteristik identitas bukan hanya dibentuk oleh ikatan kolektif, melainkan juga oleh kategori-kategori pembeda (categories of difference). Artinya bahwa, identitas selalu melekat pada setiap individu dan komunitas. Identitas merupakan karekteristik yang membedakan antara orang yang satu dengan orang yang lain supaya orang tersebut dapat dibedakan dengan yang lain. Identitas adalah pembeda antara suatu komunitas dengan komunitas lain.
Berdasarkan pandanganpandangan di atas, dapat dikatakan bahwa identitas tidak lahir begitu saja karena faktor pembawaan atau sesuatu yang dihasilkan, namun hadir di tengah masyarakat sebagai sesuatu yang dibentuk dari hasil interaksi sosial masyarakat itu sendiri. Identitas hadir karena adanya penggunaan istilah-istilah bahasa yang tepat dan sesuai dengan normanorma dari sebuah kelompok tertentu saat melakukan interaksi sosial, seperti tuturan yang terjadi di dalam kelompok tersebut dengan kontekskonteks tertentu. Penampilan wacana identitas yang memperlihatkan bermacam-macam maksud dan menampilkan efek yang bervariasi dapat diungkap dengan menyoroti aspek identitas sebagai praktik wacana. Praktik wacana menimbang bagaimana penampilan suatu teks hadir di tengah masyarakat dengan berbagai konteks.

Dengan demikian, identitas masyarakat Ciomas Kabupaten Serang dalam sastra lisan golok Ciomas ini dapat diungkap dan dianalisis lewat pemaknaan identitas dari wacana sastra lisan yang dapat lahir dari konteks yang melingkupinya dan pemaknaan tersebut, boleh dikatakan bersifat politis atau memiliki muatan tertentu. Situasi ini dapat menyebabkan hegemoni dari kelompok yang dominan terhadap kelompok yang didominasi. Oleh karena itu, pemaknaan identitas dalam wacana sastra lisan golok Ciomas ini hadir sebagai bentuk hasil interaksi manusia dalam pertuturan dengan konteks dan muatan tertentu sehingga memungkinkan terjadinya hegemoni sebagai kuasa untuk mengendalikan wacana. 


\section{Sastra Lisan}

\section{Michel Foucault}

Konsep mengenai wacana diperkenalkan oleh Michel Foucault. Wacana adalah sesuatu yang ditulis atau dikatakan atau dikomunikasikan dengan menggunakan tanda-tanda dan menandai hubungan yang lain dengan strukturalisme dan fokus dominannya pada bahasa-bagi Foucault wacana adalah "menyatukan" bahasa dengan praktik. Istilah wacana mengacu pada produksi pengetahuan melalui bahasa yang memberi makna pada benda-benda material dan praktikpraktik sosial. Meski "berada" di luar bahasa, dunia benda material dan praktik-praktik sosial diberi makna atau "ditampakkan pada kita" oleh bahasa. Dengan begitu, dunia benda material dan praktik-praktik sosial itu dibentuk secara diskursif. Wacana mengkonstruksi, mendefinisikan dan memproduksi objek-objek pengetahuan dengan cara yang dapat diterima nalar sekaligus menyingkirkan bentuk-bentuk bernalar yang lain.

Wacana menyediakan bagi kita cara-cara membincangkan suatu topik tertentu secara sama, dengan motif atau bongkahan-bongkahan ide, praktik-praktik, dan bentukbentuk pengetahuan yang diulangulang di beberapa wilayah aktivitas. Di sinilah kita bisa bicara tentang formasi diskursif, yaitu suatu pola peristiwa-peristiwa diskursif yang mengacu pada atau memunculkan keberadaan sebuah objek di beberapa wilayah. Formasi diskursif merupakan peta-peta makna yang sudah diregulasi atau cara-cara berbicara yang menjadi jalan bagi objek-objek dan prakti-praktik memperoleh makna.
Foucault berpendapat bahwa wacana meregulasi, pada suatu kondisi sosial dan kultural determinatif tertentu, bukan hanya apa yang bisa diucapkan, tapi juga siapa yang boleh mengucapkan, kapan, dan di mana. Karena itu, sebagian besar karya Foucault berkaitan dengan penyelidikan historis terhadap kekuasaan. Menurutnya, ciri utama wacana ialah kemampuannya untuk menjadi suatu himpunan wacana yang berfungsi membentuk dan melestarikan hubungan-hubungan kekuasaan dalam suatu masyarakat. Dalam banyak kajiannya mengenai penjara, seksualitas dan kegilaan, Foucault menunjukkan bahwa konsep seperti gila, tidak gila, sehat, sakit, benar, dan salah, bukanlah konsep yang abstrak yang datang dari langit tetapi dibentuk dan dilestarikan oleh wacana-wacana yang berkaitan dengan bidang-bidang seperti psikiatri, ilmu kedokteran, serta ilmu pengetahuan pada umumnya. Dalam suatu masyarakat biasanya terdapat berbagai macam wacana yang berbeda satu sama lain, namun kekuasaan memilih dan mendukung wacana tertentu sehingga wacana tersebut menjadi dominan, sedangkan wacana-wacana lainnya akan "terpinggirkan" (marginalized) atau "terpendam" (submerged).

Di sini, setiap wacana yang muncul dalam bentuk teks, percakapan atau apapun, tidak dipandang sebagai sesuatu yang alamiah, wajar, dan netral tetapi merupakan bentuk pertarungan kekuasaan. Konsep kekuasaan adalah salah satu kunci hubungan antara wacana dengan masyarakat. Kekuasaan itu dalam hubungannya dengan wacana, penting untuk melihat apa yang disebut sebagai 
kontrol. Satu orang atau kelompok mengontrol orang atau kelompok lain lewat wacana. Kontrol tidaklah harus selalu dalam bentuk fisik dan langsung tetapi juga kontrol secara mental atau psikis. Kelompok yang dominan mungkin membuat kelompok lain bertindak sesuai dengan yang diinginkan. Kenapa hanya bisa dilakukan oleh kelompok dominan? Karena mereka lebih mempunyai akses dibandingkan dengan kelompok yang tidak dominan. Kelompok dominan lebih mempunyai akses seperti pengetahuan, uang, dan pendidikan dibandingkan dengan kelompok yang tidak dominan.

\section{Cerita Rakyat sebagai Folklor dalam Tradisi Lisan}

Cerita rakyat sebagai folklor dalam tradisi lisan adalah suatu bentuk karya lisan yang lahir dan berkembang dari masyarakat tradisional yang disebarkan dalam bentuk relative tetap atau dalam bentuk standar di antara kolektif tertentu dari waktu yang cukup lama, (James Suzet Suzet Suzet 11 Danandjaja,1982: 4). Cerita rakyat telah berkembang dari tradisi lisan ke bentuk tulisan. Hal ini merupakan kemajuan teknologi yang membuat cerita rakyat memiliki keragaman versi, namun isinya tetap sama. Pada perkembangan ini disebut kelisanan primer dan kelisanan sekunder. Teeuw (1984: 297) berpendapaat bahwa "karya tersebut berkembang dari mulut ke mulut, yang berarti sastra itu berkembang melalui komunikasi pendukungnya. Secara umum cerita rakyat sebagai bagian dari karya sastra lisan, memiliki ciri yang membedakan dengan karya sastra tulis.
Ciri pembeda itu antara lain: (1) Pada umumnya karya sastra tulis disebarkan dalam bentuk tulisan, namun untuk karya sastra lisan (cerita rakyat) disebarkan secara lisan, dari mulut ke mulut dan dari satu generasi ke generasi selanjutnya. (2) Cerita rakyat yang disampaikan secara lisan mengakibatkan cerita tersebut memiliki versi yang cukup banyak, hal ini dipengaruhi oleh faktor pencerita. (3) Cerita rakyat menjadi milik bersama dalam suatu kelompok masyarakat tertentu. (4) Cerita rakyat bersifat anonim, maksudnya tokoh pengarang dari sebuah cerita rakyat tidak dapat diketahui dengan pasti, tetapi karena cerita tersebut dianggap pernah terjadi dan telah menjadi bagian dari masyarakat maka cerita rakyat tetap berkembang, walau tidak jelas siapa pengarangnya. (5) Keberadaan cerita rakyat dalam suatu masyarakat memiliki berbagai fungsi dan kegunaan dalam kehidupan kelompok masyarakat pemiliknya".

\section{Fungsi Tradisi Lisan bagi Masyarakat \\ Danandjaja mengangkat} pendapat pakar tradisi lisan William R. Bascom, bahwa secara umum tradisi lisan mempunyai fungsi penting. Fungsi tersebut sangat berhubungan dengan masyarakat antara lain:

a. Tradisi lisan berfungsi sebagai cerminan Angan-angan suatu kolektif. Misalnya, dalam masyarakat Ciomas, ada kepercayaan pada CGC bahwa "di dalam Golok Ciomas terdapat rangkaian do'a-do'a dari Sultan Banten." Kepercayaan itu sebagai cerminan harapan, cita-cita 
tentang citra pemimpin jaman dahulu yang berwibawa.

b. Tradisi lisan berfungsi sebagai alat pendidikan. Tradisi lisan yang berfungsi sebagai tradisi lisan akan memberikan pengetahuan, pengertian, dan pemahaman terhadap nilai-nilai yang hidup dan berkembang di masyarakat yang ditanamkan sejak masa kanak-kanak. Pertunjukan Debus misalnya, sarat akan nilai kehidupan yang dapat diteladani. Kata debus sering dimaknai sebagai "tembus", "ora tembus" dan "dada tembus", bahkan ada yang mengatakan bahwa debus itu kependekan dari "Dzikiran, Batin dan Shalawat" (Hudaeri, 2010: 12). Oleh karena itu, kesenian debus dapat digunakan sebagai media pendidikan juga.

c. Tradisi lisan berfungsi sebagai alat pemaksa atau pengontrol norma-norma. Masyarakat selalu dipatuhi anggota kolektifnya. Hal ini dapat kita jumpai apabila isi dalam sastra lisan tersebut mengungkapkan peraturanperaturan atau hukum-hukum yang berkembang di masyarakat baik secara eksplisit maupun implisit. Hukum tersebut diungkapkan agar setiap individu tetap menjaga harmonisasi dalam konteks hubungannya dengan Tuhan, alam sekitar atau dengan masyarakat. Masyarakat Ciomas, mempunyai ungkapan "Lain golok sembarang golok, ieu mah Golok Ciomas" (Bukan golok sembarangan golok, ini Golok Ciomas).

Ungkapan ini mengandung ajaran hidup yang bersifat "memaksa" manusia untuk 'meyakini' adanya kekuatan magis di dalam Golok
Ciomas. Barang siapa melanggarnya akan celaka besar". Fungsi yang sesuai dengan CGC ini ialah tradisi lisan berfungsi sebagai cerminan, tradisi lisan berfungsi sebagai alat pemaksa atau pengontrol normanorma, dan sebagai alat pendidikan. Dimana dari segi tradisi lisan berfungsi sebagai cerminan ialah kita dapat mencontoh sifat dan sikap positif yang dimiliki oleh CGC. Sebagai alat pendidikan ialah memberitahukan kepada pendidik dan pelajar tentang pemahaman suatu cerita rakyat dalam pembelajaran. Sebagai alat pemaksa atau pengontrol norma-norma ialah supaya masyarakat dapat mengetahui norma-norma atau hukum-hukum yang ada pada suatu daerah tertentu, supaya saling menjaga keharmonisan.

\section{METODOLOGI}

Penelitian ini merupakan salah satu kajian sastra lisan dengan metode etnografi yang bersifat deskriptif analisis kualitatif yang merupakan prosedur penelitian yang menghasilkan data deskriptif berupa kata-kata tertulis atau lisan dari orang dan prilaku yang dapat diamati (Lexy J. Moleong, 1994: 4). Fokus penelitian ini adalah sastra lisan Golok Ciomas, karena cerita rakyat merupakan fenomena humanis yang menghendaki adanya pemaparan kata-kata atau kalimat dan faktafakta budaya yang berkaitan dengan sastra lisan Golok Ciomas dan identitas masyarakatnya yang memperhatikan aspek-aspek etnografis. Sebab paham etnografis yang paling utama adalah observasi, wawancara mendalam, pengamatan terlibat, dan dokumentasi.

Gagasan metode penelitian ini mengacu pada pada James $P$. 
Spradley (2007: 63) dan Julian M. Murchison (2010: 23), "menetapakan informan, mewawancarai informan, membuat catatan etnografis, dan seterusnya. Langkah-langkah ini merupakan proses alur penelitian maju bertahap pada yang lebih luas". Sebagaimana dijelaskan oleh Murchison, bahwa tujuan etnografi adalah ..."memahami sudut pandang penduduk asli, hubungannya dengan kehidupan, untuk mendapatkan pandangannya mengenai dunianya". Lebih lanjut Spradley (2007: 11-12) berpendapat bahwa untuk mengungkap nilai-nilai kearifan lokal dari suatu tradisi perlu digunakan metode kualitatif etnografi dengan karakteristik sumber data berlatar alami dan peneliti berfungsi sebagai human instrument.

Metode yang digunakan dalam penelitian ini adalah metode deskriptif analisis. Metode deskriptif analisis disertai dengan kegiatan analisis dengan pembahasan yang lebih mendalam tentang identitas masyarakat Ciomas, konstruksi identitas melalui pola narasi (wacana lisan/teks) dari Sastra lisan Golok Ciomas, fungsi-fungsi apa saja yang bisa ditunjukkan oleh wacana lisan tersebut; dan fungsi-fungsi apa saja yang dapat berkontribusi pada wacana lisan/teks tersebut. Karena penelitian ini termasuk penelitian kualitatif, maka metode yang digunakan ialah deskriptif analisis kualitatif untuk mendeskripsikan fakta-fakta yang kemudian dianalisis. Hal tersebut tidak semata-mata mendeskripsikan atau menguraikan fakta-fakta melainkan juga memberikan penjelasan dan pemahaman secukupnya (Ratna, 2004: 53), dan (Surakhmad, 1994: 139) menjelaskan bahwa metode deskriptif tidak terbatas pada pengumpulan dan penyusunan datadata, tetapi meliputi analisis dan interpretasi dari data tersebut.

Sebelum dianalisis, data yang telah dikumpulkan, terlebih dahulu ditranskripsikan ke dalam bahasa tulisan, lalu dialihbahasakan ke dalam bahasa Indonesia. Selain melakukan penelitian di tempat lokasi penelitian, penulis juga melakukan studi kajian pustaka untuk mengetahui hal-hal yang berhubungan dengan penelitian yang sejalan, khususnya untuk mengetahuai latarbelakang kajian CGC dan hal-hal yang berhubungan dengan sastra lisan Golok Ciomas. Menurut Danandjaja (1994: 193) bahwa penelitian dengan tujuan pendokumentasian yang bersifat penelitian di tempat, setidaknya ada tiga tahapan yang harus dilalui oleh peneliti agar penelitiannya berhasil, yaitu (1) penelitian di tempat, (2) penelitian di tempat sesungguhnya, dan (3) cara pembuatan/perekaman folklor bagi pengarsipan.

Penelitian ini dilakukan untuk menganalisis dan mendeskripsikan serta menggali identitas masyarakat Ciomas, konstruksi identitas masyarakat, dan identitas masyarakat Ciomas direpresentasikan dalam CGC. Selain itu juga bagaimana nilai-nilai budaya yang berkaitan identitas masyarakat, nilai kokteks dan hubungannya dengan kehidupan masyarakat setempat yang terdapat di dalam CGC.

\section{PEMBAHASAN}

\section{Representasi Teks; Deskripsi Singkat Cerita Golok Ciomas}

Data dalam penelitian ini terdiri atas dua bagian. Data pertama berupa teks CGC, sedangkan data kedua berupa hasil merekam dan 
wawancara dengan informan. Data pertama dianalisis dengan cara mendeskripsikan CGC berdasarkan struktur tekstual untuk melihat representasi gambaran peristiwa, situasi, benda, dan keadaan di dalam teks. Selanjutnya, data ini pun dipakai untuk menganalisis relasi dan identitas yang terdapat di dalam teks. Data kedua digunakan sebagai data pendukung dan dianalisis dengan cara mengaitkan teks dengan praktik wacana dan praktik sosial pada tahap interpretasi dan eksplanasi.

Menurut penutur, kata "Golok" jika dikaitkan dengan bahasa Inggris terdiri dari dua kata, yaitu "go" yang berarti jalan dan "lock" berarti kunci sehingga CGC, hal ini merupakan sebuah kunci jalan atau kunci untuk jalan pendidikan, keharmonisan, dan untuk segala jalan yang diharapkan. Bedog dan golok berbeda, golok itu sudah pasti bedog tetapi bedog belum tentu golok. Kata Golok dan Ciomas merupakan rangkaian yang tak terpisahkan. Ciomas tidak bisa lepas dari golok itu sendiri. Hal ini merupakan bagian dari realita yang tak dapat dipungkiri dan diturunkan secara turun temurun.

Golok Ciomas merupakan salah satu budaya Islam yang kental dengan nilai-nilai spirit patriotik nasionalisme. Ciomas sendiri merupakan kepanjangan dari Ciri Obor Masyarakat dan sebagai bagian dari sebuah penanda. Ciri obor masyarakat tersebut adalah dua kalimat syahadat, ilmu tauhid, dan ilmu akidah yang kesemuanya berasal dari hal yang ilmiah. Jika diartikan terhadap pengobatan yaitu; cai (air) obat masyarakat. Di masyarakat Ciomas ini dipercaya airnya ada yang dapat menjadi obat, yaitu air yang berasal dari beberapa titik sumur kecil namun tak pernah surut. Air ini juga menjadi salah satu syarat untuk menyepuh Golok Ciomas pada bulan Mulud (pada saat Maulid Nabi). Asal-usul Ciomas sendiri yaitu digagas oleh leluhur yang dikenal dengan sebutan $\mathrm{Ki}$ Gede dan Nyi Gede pada zaman Sultan Banten. Ciomas ini didapatkan atas dzikir yang kemudian dzikir ini membawanya untuk berfikir sehinggan akhirnya membudaya (sebagai hasil dzikir, berfikir, dan berkarya) dan kemudian menjadi sebuah peradaban dari pemaknaan golok itu sendiri.

Nama Ciomas, besar dengan benda golok itu sendiri, kemanapun orang Ciomas pergi orang-orang seringkali menayakan golok tersebut. inilah yang menjadi sebab Golok dan Ciomas tidak dapat terpisahkan. Terkait dengan pencipta Golok Ciomas, konon katanya, golok Ciomas itu dibuat oleh Ki Gede dan Nyi Gede mereka adalah orang sakti-nama mereka ini hanya samaran, nama asli mereka dirahasiakan kepada siapapun, alasannya karena ilmunya yang sangat tinggi maka mereka disebut sebagai Ki Gede dan Nyi Gede. Keseharian Ki Gede dan Nyi Gede adalah membuat golok. Saking saktinya mereka tidak membuat golok dengan palu tetapi hanya dengan dipegang dan diparut saja.

Diceritakan pada masa sultan Banten, pada saat itu senjata-senjata tajam sangat dibutuhkan sementara Banten tidak memiliki senjata apa pun untu mengusir penjajah, maka melalui Ki Gede dan Nyi Gede inilah kisanak Sultan dipercayakan untuk membuat golok. Dengan kesaktian mereka, hanya dengan tiga jari golok itupun dapat tercipta. Kemudian berlanjut kepada tokoh lain yaitu $\mathrm{Ki}$ Cengkuk yang memiliki kesaktian 
yang tinggi dalam versi yang lain disebutkan beliau dari daerah Ciomas dan golok Ciomas itu penuh dengan do'a sultan.

Hal ini dipercaya oleh masyarakat Ciomas bahwa golok Ciomas menjadi simbol perdamaian walaupun banyak orang menganggap golok itu identik dengan kekerasan. Namun, golok Ciomas ini malah menjadi simbol perdamaian. Hal ini sesuai dengan filosofi golok itu sendiri yang memiliki tajam ke bawah, tumpul ke atas. Menurut narasumber, bagian atas yang tumpul pada golok ini berarti tak ada larangan terhadap Allah dan Rasul, sementara bagian bawah yang tajam berarti perjuangan dan optimisme.

Kepada Ki Gede dan Nyi Gede pihak kasultanan Banten memberikan penghargaan berupa palu pusaka yang kemudian digunakan untuk pembuatan golok Ciomas. Palu ini murni milik Ciomas, meskipun pihak museum meminta untuk memindahkannya ke tempat lain hal itu tidak dapat dilakukan. Karena ini milik Ciomas, maka Golok Ciomas tidak memiliki watak, gambar atau kalimat-kalimat tertentu. Golok Ciomas hanya membawa keselamatan, jika seseorang membawa golok tersebut sekalipun ada yang ingin mencelakainya itu tidak akan pernah terjadi. Selain itu, misalnya jika ada seseorang yang hendak marah kepada pemegang golok Ciomas, kemarahannya seketika akan hilang, bahkan penagih hutang sekalipun jika ia menagih kepada orang yang memegang golok Ciomas ia tidak akan menagihnya lagi. Hal inilah yang menurut kepercayaan masyarakat setempat adanya barokah do'a sultan karena pada dasarnya golok Ciomas ini bertujuan untuk kebaikan, jika ada yang menggunakannya untuk kejahatan itu merupakan penyalahgunaan. Jadi golok Ciomas ini merupakan senjata untuk meredam hawa nafsu sesuai dengan sejarah palu tersebut.

Dengan demikian, palu (nyi Denok dan golok) menurut penutur tidak dapat dipisahkan, hal ini diumpamakan dengan istilah guru dengan murid. Filosofi murid dengan guru bagaikan palu dengan golok. Golok sebelum menjadi golok hanya sebatas besi yang murah harganya, namun ketika dijadikan golok Ciomas harganya bisa sangat tinggi. Demikian pula untuk membuat satu golok itu tidak mudah, harus ditempa dan sebagainya seperti halnya manusia untuk menjadi pintar resikonya harus dididik. Hal ini sesuai dengan filosofi guru, makanya palu dianggap sebagai guru sehingga untuk menjadi murid yang berkualitas harus ditempa dengan guru yang berkualitas. Kata murid dalam hal ini dikaitkan dengan golok tersebut.

Sementara dari simpaynya, dikaitkan dengan agama, menurut informan bahwa ini merupakan ihsan-nya. Golok Ciomas ini berbagai macam, namun jika jenis golok Ciomas yang beratnya mencapai 2 ton yang berada di Ciomas sebagai ikon tentang pilar keagamaan yakni, Taurat, Zabur, Injil, dan Qur'an. Kemudian dalam golok ini terdapat lubang 99 lubang berkaitan dengan asmaulhusna. Adapula yang memiliki 7 lubang, namun ini hanya berupa titik yang menggambarkan jumlah kalimat syahadat. Adapula yang 25 menandakan Rasul, 9 menandakan jumlah wali songo, 5 menandakan rukun Islam atau Pancasila, 6 menandakan rukun Iman, dan lain 
sebagainya. Jadi, makna keseluruhannya tidak terlepas dari tuntunan tauhid. Kemudian, informan menegaskan jika Golok Ciomas ini terjaga keasliannya dan kelestariannya sebagai tuntunan dari nenek moyang.

Adapun Golok Ciomas yang dibuat di Ciomas yang dijadikan sebagai ikon golok Ciomas ini sebagai simbol Banten untuk dikenang dan memiliki makna filosofi tersendiri bagi Banten sebagi simbol insan kamil. Kriteria insan kamil itu sendiri di antarnya adalah pertama, mampu berdialog dengan sang pencipta melalui aqidah dan keyakinan. Ini merupakan modal utama dalam kehidupan. Kedua, mampu berdialog dengan sesama manusia dengan akhlaqul karimah. Ketiga mampu berdialog dengan alam. Ke empat, mampu berdialog dengan diri sendiri.

\section{Struktur Karya Sastra Lisan Golok Ciomas}

Struktur yang terdapat pada CGC ini memiliki hubungan yang berkesinambungan antara satu sama lain baik alur, tokoh, maupun latar. Pada analisis tokoh tercermin 3 (tiga) tokoh yang selalu hadir yakni tokoh pangeran bayi yang mempunyai kekuatan dan keistimewaannya, Ki Cengkuk, dan Ki Gede/Nyi Gede. Tampak dari ketiga tokoh tersebut berusaha saling bahu-membahu membentuk CGC. Pada analisis latar yang sangat dominan muncul yakni latar tempat berupa Kesultanan dan perkampungan (daerah Ciomas).

Berkaitan dengan proses penciptaan Golok Ciomas yang legalitas formalnya dipegang oleh sang Mpu (Pande) dengan melalui ritual serta sentuhan dan olesan dari Nyi Denok/Palu Godam yang dipercaya oleh masyarakat Ciomas sebagai kumpulan do'a dari Sultan Banten. Juga hasil dari terpaan dan pembuatan serta ritual pembuatannya kemudian dikenal dengan sebutan Golok Ciomas.

Golok Ciomas sendiri diartikan sebagai alat atau senjata sejenis parang, atau sejenis pedang yang berukuran pendek, merupakan salah satu jenis senjata khas Banten. Macam-macam bentuk dari Golok adalah; Salam nunggal, kembang kacang, malapah gedang, candung, mamancungan dan bedul mungkuk. Terdapat enam syarat dalam pembuatan Golok Ciomas yaitu waktu pembuatan, ditempa atau diulas oleh Godam Pusaka Nyi Denok. Bahan bakunya Besi Kasultanan. Ada tata cara ritualnya, dibuat di wilayah Ciomas dari air Babakan Ciomas. Adapun sebutan nama bentuk gagang Golok Ciomas yaitu wawayangan, jengkol sahulu, jebug sapasi (pinang sebelah), dan balingbing. Pada sarangka Golok Ciomas terdapat bagian-bagian yang menjadi tanda atau ciri tertentu di antaranya adalah sopal atau sompal, simeut meuting (walang bermalam), simpai (cincin-cincin sarangka) dan pepet.

Hal ini menunjukkan metodemetode yang dilakukan masyarakat dalam menjaga dan mempertahankan ke-eksistensi-an CGC. Analisis proses penciptaan dilakukan melalui proses pewarisan dan proses penciptaan. Keseluruhan dari CGC ini sama-sama diwariskan secara vertikal dan horizontal. Artinya, mereka tidak hanya menyampaikan cerita kepada keluarga kandung, namun juga kepada masyarakat melalui sistem-sistem dan aturan tidak tertulis/aturan adat-otoritas ada yang berlaku. Umumnya 
penciptaan yang dilakukan melibatkan ingatan dan lebih berdasarkan pada kespontanitasan penuturan.

Analisis konteks penuturan yang secara umum menunjukkan pergerakan aturan secara statis. Hal yang demikian ditunjukkan dari konteks situasi penuturan yang cenderung tidak berubah, seperti waktu, tujuan, media peralatan, teknik penuturan, penutur, dsb. Meskipun sedikit perubahan tampak dari waktu penuturan CGC yang sebelumnya sering dituturkan sebagai media pengantar tidur, kini dinikmati ketika sama-sama memiliki waktu senggang. Selain itu, dilihat dari aspek sosial budaya yang melatar belakangi cerita CGC menunjukkan bahwa CGC secara utuh menggambarkan pemikiran masyarakat yang telah berkembang dan merupakan wujud dari sikap manusia dalam tahap ontologis. Hal demikian ditunjukkan dari sikapsikap masyarakat yang dilakukan dalam menghadirkan solusi untuk memecahkan masalah yang dihadapinya.

Bersandar pada teori folklor yakni peraturan tak tertulis yaitu harus dipatuhi oleh norma-norma adat masyarakat Ciomas dan yang melanggar akan mendapatkan sanksi sosial. Golok Ciomas difungsikan bukan untuk digunakan sebarangan apalagi sampai melukai orang. Tapi difungsikan untuk menjaga dan melindungi pemilinya. Selain itu, CGC berfungsi sebagai media hiburan yang dipadukan dengan kesenian debus. Sehingga, makna yang terkandung dalam CGC ini, tidak terlepas dari pembelajaran mengenai kehidupan bagi setiap individu untuk meningkatkan kualitas pribadinya di kehidupan bermasyarakat. Melalui pemaknaan dalam CGC, masyarakat diajarkan untuk selalu gigih dan berusaha keras dalam mencapai harkat dan keinginan yang diimpikannya dalam mencapai makna dan kebahagiaan hidup yang hakiki.

\section{Budaya dan Mobilitas Terbuka}

Kebudayaan terbentuk melalui proses belajar atau merupakan sesuatu yang dipelajari oleh manusia melalui pengalaman hidupnya. Sesederhana apapun bentuk kebudayaan manusia, semuanya terbentuk dan hasil kebiasaan yang dipelajari oleh manusia dalam pengalaman hidupnya. Melalui pengalaman-pengalaman hidup mereka yang menjadi kebiasaan yang dipelajari inilah kemudian tcrbentuk kebudayaan dunia. Kebudayaan dunia ini merupakan sistem kebiasaan kolektif dan anggotaanggota kelompok masyarakat di seluruh dunia. Perbedaan yang bisa diamati di antara mereka adalah hasil kumulatif dari proses belajar massal di bawah kondisi-kondisi sosial dan geografi yang berbeda. Oleh karena itu, jelas bahwa budaya merupakan produk atau hasil dan proses belajar, ketimbang warisan.

Keberadaan Golok Ciomas adalah suatu karya cipta seni budaya bangsa Indonesia, yaitu hasil karya cipta para leluhur masyarakat Ciomas yang diyakini dari kalangan (alim ulama atau kiyai) atau pula disebut $\mathrm{Mpu}$, yang memiliki nilai estetika bernuansa religius (Islami) yang hingga kini masih tetap terjaga kelestariannya, baik proses (ritual) pembuatannya maupun nilai-nilai maksud dan tujuan serta manfaatnya.

Pandangan religi dalam memaknai keberadaan CGC ini, sebagian besar masyarakat Ciomas 
berpandangan bahwa sebuah konsepsi tentang keyakinan akan adanya Tuhan, malaikat, kitab, rasul, hari akhir, dan qadha serta qadhar Tuhan yang semuanya bersumber dari al-Qur'an. Di samping keyakinan dan keimanan terhadap enam hal di atas, masyarakat Ciomas juga meyakini bahwa Tuhan tidak hanya menciptakan manusia, hewan, tumbuhan, dan juga berhagai benda yang bisa diamati yang ada di alam, tetapi juga menciptakan makhluk lainnya yang tidak bisa dilihat dan diamatai yang seringkali disebut dengan jin, hantu, setan, makhluk gaib dan lain sebagainya. Oleh karena adanya konsepi tentang adanya berbagai makhluk gaib dan alam gaib, praktik magi menjadi sebuah tradisi dan menjadi karakteristik budaya pada masyarakat Ciomas. Dimensi magis hampir selalu masuk dalam beragam aktifitas sosial masyarakat terutama ketika mereka menghadapi persoalan hidup yang sulit diatasi dengan cara yang rasional.

Berkaitan dengan budaya dan tradisi masyarakat Ciomas tidak hanya kental dengan praktik magisnya, tetapi juga kental dengan berbagai ritual keagamaan. Berbagai ritual ibadah dan upacara-upacara slametan hampir selalu muncul dalam siklus kehidupan mereka. Hari-hari besar Islam misalnya pada bulan mulud Nabi, tradisi pemandian Golok Ciomas dan sepuhan serta olesan dari palu Nyi Denok yang dipercayai oleh masyarakat Ciomas sebagai kumpulan do'a-do'a Sultan Banten mempunyai keistimewaan tersendiri dan juga diisi dengan beragam aktiftas kegamaan yang selalu melibatkan seluruh anggota masyarakat.
Mobilitas merupakan proses mengerahkan pastisipan gerakan yang didasarkan atas kepercayaan tersebut sehingga tercipta solidaritas. Aktifitas-aktifitas sosial keagamaan ini tentu saja bagi masyarakat Ciomas Banten tidak hanya bermakna sebagai ritual ibadah semata, tetapi juga sebagai bentuk kesadaran diri sebagai bagian diri anggota masyarakat yang harus selalu terlibat aktif dan mengambil bagian dalam setiap kegiatan sosial. Upacara-upacara atau tradisi keagamaan seperti berbagai slametan ini, tentu saja membangkitkan emosi keagamaan bagi masyarakat Ciomas yang mempraktekan dan meyakininya, juga ada makna solidaritas sosial dan kesetaraan yang terbangun. Hal ini akan berdampak positif bagi pembangunan karakter dan membentuk jati diri/identitas masyarakat yang mencintai dan mentradisikan kearifan lokal, dan menggali nilai-nilai budaya dan nilainilai keagarnaan melalui aktifitas sosial keagamaan ini.

\section{Performing Art sebagai Penanda}

Kesenian menyebar dan dimiliki oleh setiap daerah yang ada di Banten dan merupakan representasi daerahnya masingmasing. CGC dan pertunjukan debus tidak bisa dipisahkan keduanya, yaitu: golok dan debus sebagai 'warisan budaya' leluhur masyarakat Ciomas dan dapat dikatakan sebagai penanda suatu daerah serta identitas masyarakat tersebut. Penandapenanda budaya itu terdiri dari perangkat konsep dan nilai yang mengaturnya, salah satunya adalah bentuk-bentuk kesenian debus yang dimiliki masyarakat Banten dengan gaya dan teknik yang khas. 
CGC dan pertunjukan debus secara tidak sadar dianut oleh semua masyarakat dunia, tidak terkecuali masyarakat Banten. Pada awalanya kesenian yang menggunakan Golok dan kekuatan fisik ini adalah salah satu media yang dipakai oleh para kafilah agama Islam sebagai bentuk media dakwah atau syi'ar Islam. Keahlian bermain debus adalah merupakan "buah" ketika para pengamal tarekat khusus melakukan ritual-ritual yag telah diajarkan oleh para syaikh tarekat yag kemudian dalam istilah tasawuf mencapai kondisi fana. Pada saat pengamal tarekat mencapai kondisi fana sebagai buktinya, terkadang sang syaikh tarekat membuktikannya dengan mempermainkan atraksiatraksi berbahaya seperti menghujamkan Golok ke tubuhnya tanpa terluka. Atraksi yang di luar hukum alam tersebut kemudian dipakai oleh para kafilah agama dalam hal ini kalangan elite agama Banten termasuk di dalamnya Raja Banten sendiri sebagai media dakwah Islam. Kondisi ini terjadi mengingat Banten pada saat itu adalah sebuah daerah yang masyarakatnya kental akan pemahaman mistis. Dengan kondisi seperti itu maka Raja Banten mencoba mensiasatinya dengan mempertunjukkan keahlian debus yang merupakan "bunga" dari pengamalan tarekat sebagai media perlawanan dengan cara melakukan "pribumisasi' terhadap kepercayaan mistis yang dianut oleh masyarakat Banten tersebut.

Kecenderungan untuk saling menunjukkan budaya atau kesenian debus ini sebagai performing art yang akan selalu terjadi tetapi tidak terartikulasikan sebagai pertarungan siapa yang akan unggul dan milik siapa yang paling baik tetapi lebih pada bagaimana merepresentasikan identitas masing-masing dalam konteks pergaulan sosial. Kondisi masyarakat Banten ini yang masih kuat memegang tradisi lokal praIslam pun kemudian bercampur dengan tradisi ritual debus. Kemudian debus pun terpadu dengan budaya lokal. Dengan kemajuan zaman yang semakin berkembang, maka kesenian ini pun kemudian harus terpaksa menyesuaikan agar tak ketinggalan bahkan dilupakan. Dengan kondisi seperti itu, maka tak heran jika debus saat ini banyak sekali ditemukan hal-hal yang tak pernah dipraktekan atau ada pada debus tempo dulu. Kesenian debus akhir-akhir ini nampaknya sudah mengalami pergeseran relasi dengan tarekat.

Kesenian debus saat ini telah mengalami pergesaran keterkaitan antara tarekat dengan debus sendiri. Debus saat ini telah meninggalkan atau lepas dari asalnya yakni tarekat. Pergeseran itu terlihat dari segi ritual, segi pertunjukan, segi perekrutan personil debus dan dari segi tujuannya. Dari segi spiritualnya, debus saat ini tidak mementingkan aturan-aturan yang dipraktekkan dalam tarekat, di samping itu, banyak sekali perpaduan dengan budaya lokal. Pergeseran dari pertunjukan segi tujuannya, debus saat ini lebih cenderung digunakan sebagai alat hiburan masyarakat dan dijadikan sebagai komoditi atau aset parawisata saja.

Pergaulan sosial ini dibentuk dalam tatanan budaya. Dalam konteks ini, bisa dikatakan proses pembentukannya akan melahirkan steriotipe, sehingga orang akan sudah tahu pertunjukan debus, gaya dan tekniknya yang dilengkapi 
dengan senjata tajam salah satunya Golok itu milik siapa dan dari mana asalanya ketika melihat golok dan debus itu, tanpa tidak harus datang ke daerahnya. Dalam konteks representasi identitas, disinilah terjadi titik tolak bagaimana seni itu merepresentasikan jati diri/identitas daerah tersebut.

Konteks inilah yang kemudian menunjukkan kekuatan wacana sangat berperan untuk mendobrak semua batasan-batasan terlebih dahulu telah terdefinisikan. Dominasi wacana dalam upaya pembentukan ini menjadi strategis karena berangkat dari pemahaman bahwa manusia pada dasarnya adalah makhluk sosial yang sudah tentu dalam kesehariannya terjadi interaksi, sehingga strategi dominasi wacana menjadi sesuatu yang sangat ampuh untuk urusan membentuk dan dibentuk melalui wacana tersebut karena wacana selalu berhubungan dengan tindakan dan sangat berpotensi mengarahkan setiap orang untuk bertindak. Kondisi inilah yang terjadi ketika sebuah seni dari daerah tertentu menempatkan wacana sebagai wahana merepresentasikan identitas tidak menutup kemungkinan proses itu akan berjalan dengan baik karena yang bisa membendung wacana itu sendiri haruslah dengan wacana.

\section{SIMPULAN}

Pada masyarakat Ciomas, CGC menjadi sebuah ikon yang merepresentasikan jati dirinya dan berupaya memaknai 'warisan budaya' tersebut menuju proses identifikasi atau berupaya untuk mendapatkan identitas tertentu. Identitas ini tidak lagi kemudian berbicara tentang siapa dirinya sesunguhnya, tetapi lebih kepada seperti apa masyarakat Ciomas saat ini. Yaitu ketika citra (image) mengalahkan sebuah kenyataan yang akhirnya melahirkan mitologi masyarakat Ciomas yang mempunyai ciri khas.

Dengan demikian, dalam suatu produk budaya yang terbentuk lewat cerita rakyat Golok Ciomas, terbukti kreativitas yang unggul dan khas ini berasal dari masyarakat Ciomas. Keunggulan dan kekhasannya terlihat dari aspek bahasa, zaman kelahirannya, aspek kepercayaan yang ideal; keislaman, penokohan, latar, dan struktur ceritanya. Hakikatnya kreativitas ini memperlihatkan satu gambaran atas identitas masyarakat Ciomas yang ideal, unggul, dan khas.

Di lain pihak, proses identifikasi atau upaya menuju identitas masyarakat Ciomas ini sangat kuat berkaitan dengan 'kekuasaan' dan kebijakan pemerintah dengan menerbitkan dan mencetak sastra lisan/cerita rakyat Golok Ciomas sebagai sebuah 'wacana tandingan'. Karya yang sudah dicetak tersebut mampu menerobos ruang-ruang yang ada, namun pada sisi yang lain terdapat kurangnya pemahaman masyarakat sekitar sehingga menjadikan kebudayaan (baca: CGC) hanya dijadikan sebagai alat pengukuhan 'kekuasaan' semata dengan mengabaikan masyarakat atau komunitas dari pemilik kebudayaan CGC tersebut. Alhasil, masyarakat hanya dimanfaatkan ketika ada kepentingan penguasa. Sebagai akibatnya, upaya mengembangkan kebudayaan lokal tidak serta merta masyarakatnya juga ikut dikembangkan tetapi pengabaian itu mampu menciptakan space-ruang, 
yang sengaja dibiarkan kosong untuk dimaknai yaitu antara kecanggihan dan keterbelakangan.

\section{DAFTAR PUSTAKA}

Teks mengenai metode, teori dan kritik sastra:

Ary, D., Jacobs, L. C., Razavieh, A., \& Sorensen, C. 2006. Introduction to Research in Education (International Student Edition). Belmont: Thompson Higher Education.

Ahimsa Putra, Shri, Heddy. 2001. Strukturalisme Levi-Strauss Mitos dan Karya Sastra. Jakarta: Galang Press

Danandjaja, James. 1994. Folklor Indonesia: Ilmu Gosip, dongeng, dan lain lain. Jakarta: PT Grafiti Press.

de Fina, Anna, Schiffrin, Deborah, \& Bamberg, Michael. 2006. Discourse and identity. Cambridge: Cambridge University.

Endraswara, Suwardi. 2003. Metodologi Penelitian Sastra. Yogyakarta: Pustaka Widyautama.

2005. Tradisi Lisan Jawa. Yogyakarta: Narsi.

2008. Metodologi Penelitian Sastra. MedPress (anggota IKAPI Yogyakarta.

Fadillah, Mohammad Ali. (2005). Identitas Banten: Reposisi Nilai Budaya dalam Modernisasi. Dalam Agus
Sutisna.(ed.). Banten Melangkah Menuju Kemandirian, Kemajuan, dan Kesejahteraa (hal.74). Serang: Biro Humas Provinsi Banten.

Fischer, Joseph, 1994. The Folk Art of Java, Oxford University Press, Kuala Lumpur.

Hall, Stuart. 1990. Cultural Identity and Diaspora. London: Harvester Wheatsheaf

1996. The New Ethnicities dalam Ethnicity, John Hutchinson dan Antony D. Smisth (Eds), New York: Oxford University Press

Harvey, S.P. 1953. The Oxford Companion to English Literature. Oxford at the Clarendon Press.

Harold Brunvand, 1996. The Study of American Folklore, Garland Publishing, Inc. New York \& London, 1996

Jabrohim (ed.). 2001. Metodologi Penelitian Sastra. Hanindita Graha Widia: Jogjakarta.

Kutha Ratna, Ny. 2010. Sastra dan Cultural Studies: Representasi Fiksi dan Fakta. Yogyakarta: Pustaka Pelajar.

$\begin{array}{lrr} & \text { 2008. } & \text { Teori, } \\ \text { Metode, dan } & \text { Teknik } \\ \text { Penelitian Sastra dari } & \text { Strukturalisme } & \text { hingga } \\ \text { Poststrukturalisme } & \\ \text { Perspektif Wacana } & \text { Naratif. } \\ \text { Yogyakarta: } & \text { Pustaka } \\ \text { Pelajar. } & \end{array}$


Lexy J. Moleong, Metodologi Penelitian Kualitatif, Remaja Karya, Bandung, 1994, hlm. 4

Levi-Strauss, Claude. 1997. Mitos Dukun dan Sihir. Yogyakarta: Kanisius.

LP-3SDMDB, 2011. Golok Ciomas, Hikayat dan Keistimewaannya, Seri Budaya Banten, LP3SDMDB dan PGRI Provinsi Banten

Michel Foucault, The Archaeology of Knowledge and the Discourse on Language, translated from the french by a. M. Sheridan smith, pantheon books, new york, 1971

,The Order of Things, An archaeology of the Human Sciences, London and New York,1989

\section{,Wacana}

Kuasa/Pengetahuan, diterj. Yudi Santoso, (Yogyakarta: Bentang Budaya, 2002), hal. 167.

,The Archaeology of Knowledge and the Discourse on Language, translated from the french by a. M. Sheridan smith, pantheon books, new york, 1971

Arkeologi

pengetahuan,

dialihbahasakan oleh Inyiak

Ridwan Muzir, IRCiSoD, Sampangan wonosari

Jogjakarta, 2012
The Order of

Things, An archaeology of the Human Sciences, London and New York,1989

Arkeologi Ilmu-Ilmu

Kemanusiaan,

dialihbahasakan oleh B.

Priambodo dan Pradana

Boy, Pustaka Pelajar,

Celeban Timur Jogyakarta, 2007

edited by colin

gordon, translated by colin gordon, leo marshall and john mepham, kate soper. Power/knowledge, selected interviews and other writings 1972-1977

, Wacana

Kuasa/Pengetahuan, diterj. Yudi Santoso, (Yogyakarta: Bentang Budaya, 2002),

Pudenta MPSS (editor), Metodologi Kajian Tradisi Lisan, Yayasan obor Indonesia, Jakarta, 2015

Sukatman, 2011. Mitos dalam Tradisi Lisan Indonesia, Penerbit: Center For Society Studies (CSS) Jember.

Taum Yapi, Yoseph. 2011. Studi Sastra Lisan: Sejarah, Teori, Metode dan Pendekatan, Disertai dengan Contoh Penerapannya. Yogyakarta: Lamalera.

Thornborrow, Joanna. (2007). Bahasa dan Identitas. Dalam Abdul Syukur Ibrahim. (ed.). Bahasa, Masyarakat, 
Jurnal al-Tsaqafa Volume 13, No. 02, Juli 2016

dan Kekuasaan (hal.238).

Yogyakarta: Pustaka Pelajar

Zaimar, Oke K.S. 2015. Metodologi Penelitian Sastra Lisan, Bab XVIII. Dalam kumpulan hasil penelitian: Metodologi Kajian Tradisi Lisan (edisi Revisi), Editor Pudentia MPSS. Yayasan Pustaka Obor Jakarta. 